\title{
Using 5,10,15,20-tetra(4-nitrophenyl)porphyrin as a fluorescent chemosensor to determine $\mathrm{Ru}^{3+}$
}

\author{
Tienkul Kangwanwong ${ }^{\mathrm{a}}$, Wanchai Pluempanupat ${ }^{\mathrm{a}}$, Waraporn Parasuk $^{\mathrm{a}}$, Helen E. Keenan ${ }^{\mathrm{b}}$, \\ Apisit Songsasen $^{\mathrm{a}, *}$ \\ ${ }^{a}$ Department of Chemistry and Centre for Innovation in Chemistry, Faculty of Science, Kasetsart University, \\ Bangkok 10900 Thailand \\ b David Livingstone Centre for Sustainability, Department of Civil Engineering, University of Strathclyde, \\ Glasgow, Scotland G1 1XN, United Kingdom
}

*Corresponding author, e-mail: fsciass@ku.ac.th

Received 11 Jan 2012

Accepted 12 Jun 2012

\begin{abstract}
The 5,10,15,20-tetra(4-nitrophenyl)porphyrin (TNPP) has been synthesized using the reaction of pyrrole and 4-nitrobenzaldehyde in the presence of propionic acid. The TNPP was used as a new fluorescent chemosensor to determine $\mathrm{Ru}^{3+}$ with higher selectivity than other ions such as $\mathrm{Hg}^{2+}, \mathrm{CH}_{3} \mathrm{Hg}^{+}, \mathrm{Ag}^{+}, \mathrm{Co}^{2+}, \mathrm{Cd}^{2+}, \mathrm{Ni}^{2+}, \mathrm{Cr}^{3+}, \mathrm{Fe}^{3+}, \mathrm{Cu}^{2+}$, or $\mathrm{Zn}^{2+}$. The response of the new chemosensor is reported in the form of fluorescence quenching, which is attributed to the metalloporphyrin formation of Ru-TNPP complex with $1: 1$ stoichiometric ratio $\left(K_{\text {stab }}=2.04 \times 10^{8}\right)$. The synthesized fluorescence chemosensor can be used to determine $\mathrm{Ru}^{3+}$ with a detection limit of $0.89 \mu \mathrm{M}(90 \mathrm{ppb})$ and a linear quantification range between 3 and $25 \mu \mathrm{M}$. Therefore, the synthesized chemosensor could be used as a new fluorescence chemosensor for the quantitative analysis of $\mathrm{Ru}^{3+}$ with satisfactory results.
\end{abstract}

KEYWORDS: porphyrin derivative, porphyrin complex of $\mathrm{Ru}^{3+}$, ion selectivity

\section{INTRODUCTION}

Among several metal cations, ruthenium ion is widely used in many applications including catalyst ${ }^{1,2}$, dyesensitized solar cell ${ }^{3-5}$, and in medicine as an anticancer agent ${ }^{6-8}$. However, extensive use of ruthenium ion could lead to accumulation of wastes harmful to the environment, as ruthenium ion exhibits various forms of toxicity ${ }^{9}$. All ruthenium-containing compounds are considered toxic because they can stain skin strongly, and ingested ruthenium can also be retained strongly in bone ${ }^{10}$. Hence, the determination of ruthenium ion in an environment has gained importance due to environmental toxicity concerns. Various methods to determine $\mathrm{Ru}^{3+}$, such as chromatography, atomic absorption, and ICP-MS have been previously reported in the literature ${ }^{11-14}$. However, these methods require either sophisticated operation or difficult sample preparation. Therefore, the development of simpler methods to determine ruthenium ion is crucial and remains an attractive research topic in environmental toxicology and analytical chemistry.

Nowadays, the design and development of highly selective and fluorescent sensors for transition-metal cations with high selectivity have been widely explored due to the high sensitivity and selectivity of fluorescence method ${ }^{15,16}$. The porphyrin macrocycles have been used as fluorophore owing to their high absorption coefficient in the visible range, tunable fluorescence emission, large Stoke shift, which can minimize fluorescence background and high photoand chemical-stability ${ }^{17-19}$. In addition, porphyrin metallation can be used as a method to determine metal cations when emission properties of metalloand free base-porphyrin are significantly different ${ }^{20}$.

Herein, 5,10,15,20-tetra(4-nitrophenyl)porphyrin (TNPP) was synthesized and then used as a fluorescent chemosensor for the determination of $\mathrm{Ru}^{3+}$. To the best of our knowledge, TNPP has been synthesized by various methods ${ }^{21-23}$ but it has never been used as a tool to determine the amount of any ions before. Consequently, it would be beneficial to use TNPP as a new fluorescent chemosensor to determine $\mathrm{Ru}^{3+}$.

\section{MATERIALS AND METHODS}

\section{Reagents and chemicals}

All reagents and solvents were commercially available and used as received without further purification. The standard solutions of metal cations were prepared from a standard solution $1000 \mathrm{ppm}$ atomic absorption spectroscopy (AAS) grade except mercury ion 
$(\mathrm{Hg}(\mathrm{II}))$ and methylmercury ion $\left(\mathrm{CH}_{3} \mathrm{Hg}(\mathrm{I})\right)$, which were used from solid chloride salt.

\section{Apparatus}

The ${ }^{1} \mathrm{H}$ - NMR spectra were recorded on an INNOVA VARIAN NMR spectrometer $400 \mathrm{MHz}$ spectrometer with chemical shifts (in ppm) relative to $\mathrm{CDCl}_{3}$. The FT-IR spectra were obtained by Perkin Elmer system 2000 Fourier transform infrared spectrometer using $\mathrm{KBr}$ pellets in the range of $4000-400 \mathrm{~cm}^{-1}$. Electrospray ionization mass spectrometry (ESI-MS) was performed on a Bruker microTOF mass spectrometer using tetrahydrofuran (THF) as a carrier solvent. Fluorescence spectra were recorded on a Varian Cary Eclipse fluorescence spectrophotometer

\section{Synthesis of 5,10,15,20-tetra(4-nitrophenyl)- porphyrin (TNPP)}

The TNPP was synthesized according to a previously reported protocol ${ }^{24}$. In brief, 4-nitrobenzaldehyde and pyrrole were heated to reflux in the presence of propionic acid. TNPP was obtained in $20 \%$ yield and was characterized by spectroscopic techniques. ${ }^{1} \mathrm{H}$ NMR $\left(400 \mathrm{MHz}, \mathrm{CDCl}_{3}\right): \delta 8.82(\mathrm{~s}, 8 \mathrm{H}$, pyrrole$\mathrm{H}), 8.66(\mathrm{~d}, 8 \mathrm{H}, J=8.8 \mathrm{~Hz}, \operatorname{ArH}), 8.40(\mathrm{~d}, 8 \mathrm{H}$, $J=8.8 \mathrm{~Hz}$, ArH). ESI-MS: $(m / z) 795.7[\mathrm{M}+\mathrm{H}]^{+}$. FT-IR (KBr, cm $\left.{ }^{-1}\right): 846$ (s), 864 (s), 963 (s), 1223 (w), 1344 (s), 1400 (w), 1516 (s), 1595 (s), 1679 (w), $3313(w)$.

\section{General spectroscopic method}

Methanol and THF were used as solvents for spectroscopic experiments without any further purification. The stock solution of $\mathrm{Hg}^{2+}$ and $\mathrm{CH}_{3} \mathrm{Hg}^{+}$were prepared from their corresponding chloride salts. The stock solutions of $\mathrm{Ru}^{3+}, \mathrm{Ag}^{+}, \mathrm{Co}^{2+}, \mathrm{Cd}^{2+}, \mathrm{Ni}^{2+}, \mathrm{Cr}^{3+}$, $\mathrm{Fe}^{3+}, \mathrm{Cu}^{2+}$, and $\mathrm{Zn}^{2+}$ were prepared from $1000 \mathrm{ppm}$ AAS standard solution.

The stock solution of TNPP was prepared by dissolving TNPP in THF. For $1 \mathrm{mM}$ stock solutions of metal cations, an appropriate amount of each metal cation was dissolved in methanol and the volume was adjusted to $100 \mathrm{ml}$ in a volumetric flask. Then, all solutions were further diluted to $0.1 \mathrm{mM}$.

Fluorescence spectra were recorded at room temperature. The complex solution of Ru-TNPP was prepared by adding $250 \mu \mathrm{l}$ of $1 \mathrm{mM}$ stock solution of $\mathrm{Ru}^{3+}$ to $2.5 \mathrm{ml}$ solution of $0.1 \mathrm{mM}$ TNPP. Then, volume was adjusted to $10 \mathrm{ml}$ by THF. For the fluorescence titration, $10 \mu \mathrm{l}$ aliquots of $\mathrm{Ru}^{3+}$ solution (from $0.1 \mathrm{mM}$ and $1 \mathrm{mM}$ of $\mathrm{Ru}^{3+}$ solution in methanol) were added to $2.5 \mathrm{ml}$ TNPP solution $(0.1 \mathrm{mM}$ in THF). The excitation and emission wavelength for

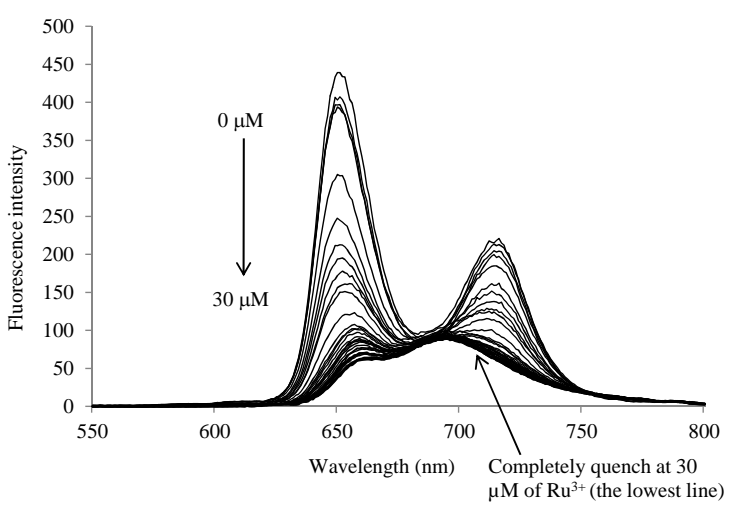

Fig. 1 Fluorescence titration spectra of TNPP $(25 \mu \mathrm{M})$ upon the addition of $\mathrm{Ru}^{3+}$ at different concentrations $(0-30 \mu \mathrm{M})$.

all measurements were fixed at 430 and $651 \mathrm{~nm}$, respectively. The UV-Vis spectroscopic measurements were performed using a Perkin Elmer Lambda 35 UV-Vis spectrophotometer at room temperature. All spectroscopic measurements were conducted using quartz cuvettes with $1 \mathrm{~cm}$ path length.

\section{RESULTS AND DISCUSSION}

\section{Fluorescence spectra and fluorescence titration}

The fluorescence spectrum of TNPP shows a sharp band with a maximum at $651 \mathrm{~nm}$. When $\mathrm{Ru}^{3+}$ was added to the TNPP solution, fluorescence quenching was observed. In order to determine the amount of $\mathrm{Ru}^{3+}$ required to completely quench the fluorescence signal from TNPP, the fluorescence titrations were performed (Fig. 1). It was found that the fluorescence of TNPP was almost completely quenched when one equivalent of $\mathrm{Ru}^{3+}$ was added, indicating the formation of TNPP complex.

To determine the linear range and detection limit, the fluorescence quenching efficiency $\left(I_{0} / I\right)$ values of TNPP were plotted against concentrations of $\mathrm{Ru}^{3+}$. The plot exhibited a linear relationship between $I_{0} / I$ and concentration of $\mathrm{Ru}^{3+}$ over the range of 3$25 \mu \mathrm{M}$. The regression equation is expressed as follows: $y=0.2362 x+0.6752\left(R^{2}=0.9849\right)$, where $y=$ fluorescence quenching efficiency and $x=$ concentration of $\mathrm{Ru}^{3+}$. The limit of detection (defined as $y_{\mathrm{b}} \pm 3 s_{\mathrm{b}}$ ) for quantifying $\mathrm{Ru}^{3+}$ by TNPP was determined to be $0.89 \mu \mathrm{M}$, which is equal to $89.95 \mathrm{ppb}^{25,26}$.

\section{Absorption spectra}

Absorption spectra of TNPP in the absence and in the presence of $\mathrm{Ru}^{3+}$ were recorded (Fig. 2). The absorption spectrum of TNPP exhibits a Soret band 


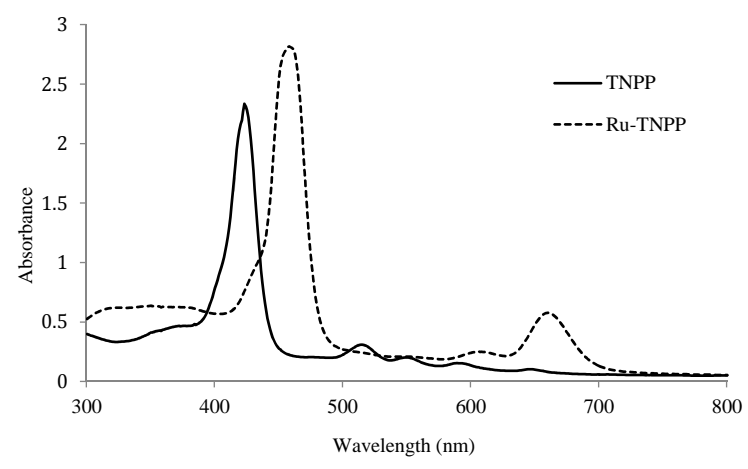

Fig. 2 UV-Vis spectra of TNPP $(25 \mu \mathrm{M})$ in the absence and in the presence of $\mathrm{Ru}^{3+}(25 \mu \mathrm{M})$.

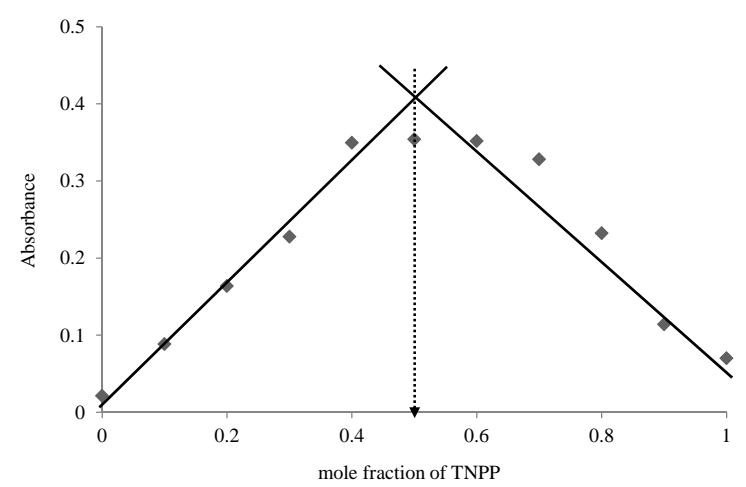

Fig. 3 Job plot for the determination of stoichiometry of $\mathrm{Ru}$-TNPP complex.

at $423 \mathrm{~nm}$ and Q band at $513 \mathrm{~nm}$. Upon addition of $\mathrm{Ru}^{3+}$, the absorption spectrum displays a shift of Soret band and Q band to $453 \mathrm{~nm}$ and $601 \mathrm{~nm}$, respectively. These spectroscopic characters indicate the formation of Ru-TNPP complex.

To determine the stoichiometry of Ru-TNPP complex, Job's method was conducted ${ }^{27}$. The plot between absorbance and mole fractions of TNPP at $455 \mathrm{~nm}$ is shown in Fig. 3. It was found that the stoichiometric ratio of Ru-TNPP complex was 1:1. Moreover, from Job's method, the stability constant was calculated to be $2.04 \times 10^{8}$ for the Ru-TNPP com$\mathrm{plex}^{27}$. Based on these results, a possible structure of $\mathrm{Ru}-\mathrm{TNPP}$ complex was proposed, where tetrapyrrolic cavity of the TNPP provides a coordination site for $\mathrm{Ru}^{3+}$ and, due to the literature reviews ${ }^{28,29}$, the solvent molecules such as $\mathrm{MeOH}$ and/or THF can provide 6 coordinations with $\mathrm{Ru}^{3+}$ on the axial position (Fig. 4).

To understand the occurrence of Ru-TNPP complex, the quantum chemical calculation of TNPP was carried out. The optimized structure of TNPP us-

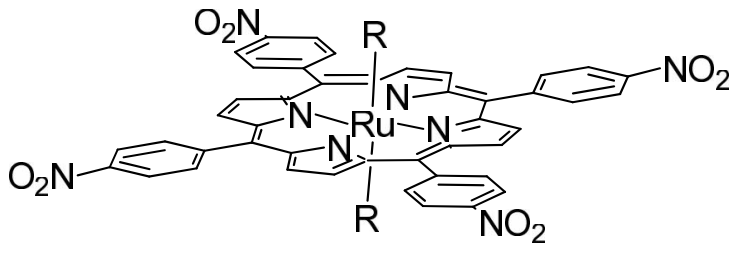

Fig. 4 A possible structure of Ru-TNPP complex $(\mathrm{R}=$ $\mathrm{MeOH}$ and/or THF).

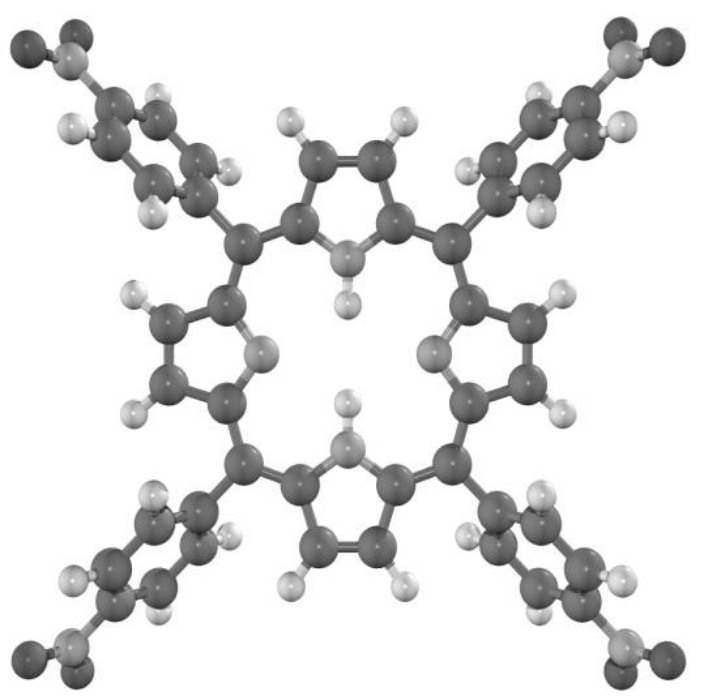

Fig. 5 The optimized structure of TNPP.

ing GaUSSIAn03 program is shown in Fig. 5. The calculation uses density functional theory at B3LYP level of theory and the $6-31 \mathrm{G}^{*}$ basis set. From the optimized structure, the diameter of TNPP cavity is $4.2 \AA$. Comparing to the diameter of $\mathrm{Ru}^{3+}$, which is $(1.64 \AA)^{30}$. One can see that the size of $\mathrm{Ru}^{3+}$ is small enough to fit in the tetrapyrrolic cavity of the TNPP. These results support the occurrence of RuTNPP complex via addition of $\mathrm{Ru}^{3+}$ to the solution of TNPP.

\section{Selectivity}

To investigate the selectivity of TNPP ligand for $\mathrm{Ru}^{3+}$ over other metal cations, some cations $\left(\mathrm{Hg}^{2+}\right.$, $\mathrm{CH}_{3} \mathrm{Hg}^{+}, \mathrm{Ag}^{+}, \mathrm{Co}^{2+}, \mathrm{Cd}^{2+}, \mathrm{Ni}^{2+}, \mathrm{Cr}^{3+}, \mathrm{Fe}^{3+}, \mathrm{Cu}^{2+}$, and $\mathrm{Zn}^{2+}$ ) were analysed and the fluorescence responses of these cations were compared with that of $\mathrm{Ru}^{3+}$. It was found that fluorescence quenching response of TNPP in the presence of $\mathrm{Ru}^{3+}$ is greater than any other cations (Fig. 6). Moreover, interferences from other cations were also studied. The addition of aforementioned metal cations into the solution of TNPP 


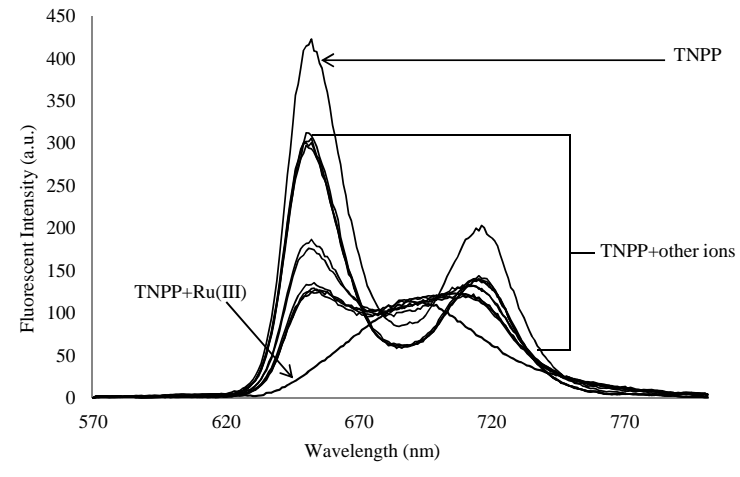

Fig. 6 The fluorescence spectra of TNPP $(25 \mu \mathrm{M})$ and TNPP in the presence of various metal cations, which are $\mathrm{Hg}(\mathrm{II}), \mathrm{CH}_{3} \mathrm{Hg}(\mathrm{I}), \mathrm{Ag}(\mathrm{I}), \mathrm{Cd}(\mathrm{II}), \mathrm{Cr}(\mathrm{III}), \mathrm{Fe}(\mathrm{III}), \mathrm{Co}(\mathrm{II})$, $\mathrm{Ni}(\mathrm{II}), \mathrm{Cu}(\mathrm{II}), \mathrm{Zn}$ (II) at the concentration of $25 \mu \mathrm{M}$ at the stoichiometric ratio of $1: 1$.

Table 1 Fluorescent sensing of $\mathrm{Ru}^{3+}$ by TNPP $(25 \mu \mathrm{M})$ in the presence of interfering cations.

\begin{tabular}{lccccccc}
\hline Ion & \multicolumn{7}{c}{ Molar ratio of interference ion : Ru(III) } \\
\cline { 2 - 7 } & $0.007: 1$ & $0.01: 1$ & $0.02: 1$ & $0.1: 1$ & $0.5: 1$ & $1: 01$ & $10: 01$ \\
\hline $\mathrm{Hg}(\mathrm{II})$ & - & - & - & - & + & + & + \\
$\mathrm{CH}_{3} \mathrm{Hg}(\mathrm{I})$ & - & - & - & - & + & + & + \\
$\mathrm{Ag}(\mathrm{I})$ & - & - & - & - & + & + & + \\
$\mathrm{Co}(\mathrm{II})$ & - & - & - & + & + & + & + \\
$\mathrm{Cd}(\mathrm{II})$ & - & - & - & - & + & + & + \\
$\mathrm{Ni}(\mathrm{II})$ & - & - & - & + & + & + & + \\
$\mathrm{Cr}(\mathrm{III})$ & - & - & - & - & + & + & + \\
$\mathrm{Fe}(\mathrm{III})$ & - & - & - & - & + & + & + \\
$\mathrm{Cu}(\mathrm{II})$ & - & - & - & + & + & + & + \\
\hline
\end{tabular}

$+=$ Interfere

$-=$ Not interfere

containing $\mathrm{Ru}^{3+}$ resulted in negligible change of fluorescence intensity at low concentration, whereas all cations could interfere with the analysis of $\mathrm{Ru}^{3+}$ at high concentration (Table 1). However, at the ratio of $0.1: 1$ (interference ion: $\mathrm{Ru}^{3+}$ ), the determination of $\mathrm{Ru}^{3+}$ by TNPP was strongly interfered. From HSAB theory ${ }^{30}$, the results might be due to the borderline acid character of these cations and the size of these cations that allow them to be coordinated by the TNPP. Besides, it is well known that porphyrins can form stable complex with metal ions such as $\mathrm{Zn}, \mathrm{Cu}, \mathrm{Co}$, or $\mathrm{Ni}$ which are the main interference ions. Although there are some interferences for using TNPP as a fluorescent chemosensor, the interferences from selected metal cations are negligible at low concentration of interference ions. Based on the results presented here, using TNPP as fluorescence chemosensor could be a new approach for determining $\mathrm{Ru}^{3+}$ with low limit of detection.
Table 2 The determination of $\mathrm{Ru}^{3+}$ in synthetic waste water samples.

\begin{tabular}{lccc}
\hline Sample & $\begin{array}{c}\mathrm{Ru}^{3+} \text { spiked } \\
(\mu \mathrm{M})\end{array}$ & $\begin{array}{c}\mathrm{Ru}^{3+} \text { concentration }(\mu \mathrm{M}) \\
(\text { mean } \pm \mathrm{SD}, n=3)\end{array}$ & $\begin{array}{c}\text { Recovery } \\
(\%)\end{array}$ \\
\hline 1 & 5 & $4.62 \pm 0.37$ & 92.4 \\
2 & 10 & $9.44 \pm 0.21$ & 94.4 \\
3 & 15 & $15.74 \pm 0.18$ & 104.9 \\
\hline
\end{tabular}

The synthesized porphyrin chemosensor was used in the determination of $\mathrm{Ru}^{3+}$ in the synthetic samples in order to display how TNPP work. Different samples were prepared by adding other ions such as $\mathrm{Cu}^{2+}$, $\mathrm{Zn}^{2+}$, and $\mathrm{Ni}^{2+}$ in order to mimic the actual waste water content from industries ${ }^{31,32}$. Aliquots of different concentrations of $\mathrm{Ru}^{3+}$ were added to the prepared water sample (having other ions 100 times lower than $\mathrm{Ru}^{3+}$ concentration). These samples were then analysed by treating with the synthesized TNPP followed by the fluorescence measurement. The recoveries of spiked $\mathrm{Ru}^{3+}$ (compared to the blank) determined by TNPP displayed satisfactory results (Table 2).

\section{Conclusions}

In summary, TNPP was synthesized and used as a new fluorescence chemosensor for the analysis of $\mathrm{Ru}^{3+}$. The complexation between TNPP and $\mathrm{Ru}^{3+}$ quenches the fluorescence of TNPP at $651 \mathrm{~nm}$. The stoichiometry of the complex between TNPP and $\mathrm{Ru}^{3+}$ was determined to be $1: 1$ by Job's method with a stability constant of $2.04 \times 10^{8}$. Although the selectivity of TNPP to $\mathrm{Ru}^{3+}$ at high concentration level of interference ions is poor, the fluorescent chemosensor TNPP is still a convenient way to determine $\mathrm{Ru}^{3+}$ in water samples without sophisticate method in case of low level of interference ions. Moreover, the results support the use of TNPP as a new approach for the fluorescence quantification of $\mathrm{Ru}^{3+}$.

Acknowledgements: The authors would like to thank the Department of Chemistry, Kasetsart University and the Centre of Excellence for Innovation in Chemistry (PERCHCIC), Commission on Higher Education, Ministry of Education for financial support. The authors would also like to thank the Faculty of Science, Kasetsart University for Bilateral Research Collaboration grant for this study. Besides, I wish to express my sincere gratitude to Dr Pitak Chuawong, Dr Sornnarin Bangkedphol, and Miss Kanokwan Kongpatpanich for their helpful assistance.

\section{REFERENCES}

1. Lee JW, Popov BN (2007) Ruthenium-based electrocatalysts for oxygen reduction reaction-a review. 
J Solid State Electrochem 11, 1355-64.

2. Romero I, Rodríguez M, Sens C, Mola J, Kollipara MR, Francàs L, Mas-Marza E, Escriche L, Llobet A (2008) $\mathrm{Ru}$ complexes that can catalytically oxidize water to molecular dioxygen. Inorg Chem 47, 1824-34.

3. Gratzel M (2003) Dye-sensitized solar cells. J Photochem Photobiol C Photochem Rev 4, 145-53.

4. Nazeeruddin MK, Klein C, Liska P, Grätzel M (2005) Synthesis of novel ruthenium sensitizers and their application in dye-sensitized solar cells. Coord Chem Rev 249, 1460-7.

5. Kuang D, Klein C, Snaith HJ, Humphry-Baker R, Zakeeruddin SM, Grätzel M (2008) A new ioncoordinating ruthenium sensitizer for mesoscopic dyesensitized solar cells. Inorg Chim Acta 361, 699-706.

6. Antonarakis ES, Emadi A (2010) Ruthenium-based chemotherapeutics: are they ready for prime time? Canc Chemother Pharmacol 66, 1-9.

7. Gras M, Therrien B, Süss-Fink G, Zava O, Dyson PJ (2010) Thiophenolato-bridged dinuclear arene ruthenium complexes: a new family of highly cytotoxic anticancer agents. Dalton Trans 39, 10305-13.

8. Pelletier F, Comte V, Massard A, Wenzel M, Toulot S, Richard P, Picquet M, Le Gendre P, Zava O, Edafe F, Casini A, Dyson PJ (2010) Development of bimetallic titanocene-ruthenium-arene complexes as anticancer agents: Relationships between structural and biological properties. J Med Chem 53, 6923-33.

9. Krebs RE (1998) The History and Use of Our Earth's Chemical Elements, Greenwood Publishing Group, London.

10. Lenntech BV (2011) Ruthenium [Online], http://www. lenntech.com/periodic/elements/ru.htm.

11. Hu Y, Vanhaecke F, Moens L, Dams R, Geuens I (1999) Determination of ruthenium in photographic materials using solid sampling electrothermal vaporization inductively coupled plasma mass spectrometry. J Anal At Spectrom 14, 589-92.

12. Reeves RR, Williams HP, Bedenbaugh JH (1977) Spectrophotometric determination of ruthenium using 1pentyl 4,6-dihydroxy-5-nitrosopyridine-3-carboxylate. Mikrochim Acta 67, 489-93.

13. De Wael K, Adriaens A, Temmerman E (2006) The electrochemical detection of $\mathrm{Ru}(\mathrm{II})$ in a methyl methacrylate solution. Talanta 68, 1247-51.

14. Szpunar J, Makarov A, Pieper T, Keppler BK, Lobinski $R$ (1999) Investigation of metallodrug-protein interactions by size-exclusion chromatography coupled with inductively coupled plasma mass spectrometry (ICPMS). Anal Chim Acta 387, 135-44.

15. Valeur B, Leray I (2000) Design principles of fluorescent molecular sensors for cation recognition. Coord Chem Rev 205, 3-40.

16. Luo HY, Jiang JH, Zhang XB, Li CY, Shen GL, Yu RQ (2007) Synthesis of porphyrin-appended terpyridine as a chemosensor for cadmium based on fluorescent enhancement. Talanta 72, 575-81.
17. Weng YQ, Teng YL, Yue F, Zhong YR, Ye BH (2007) A new selective fluorescent chemosensor for $\mathrm{Cu}$ (II) ion based on zinc porphyrin-dipyridylamino. Inorganic Chemistry Communications 10, 443-6.

18. Weng YQ, Yue F, ZhongYR, Ye BH (2007) A copper(II) ion-selective on-off-type fluoroionophore based on zinc porphyrin-dipyridylamino. Inorg Chem 46, 7749-55.

19. Falk JE (1964) Porphyrin and Metalloporphyrins, Elsevier Publishing Company, New York.

20. Li CY, Zhang XB, Dong YY, Ma QJ, Han ZX, Zhao Y, Shen GL, Yu RQ (2008) A porphyrin derivative containing 2-(oxyrnethyl)pyridine units showing unexpected ratiometric fluorescent recognition of $\mathrm{Zn}^{2+}$ with high selectivity. Anal Chim Acta 616, 214-21.

21. Adler AD, Longo FR, Finarelli JD, Goldmacher J, Assour J, Korsakoff L (1967) A simplified synthesis for meso-tetraphenylporphine. J Org Chem 32, 476-7.

22. Kim JB, Leonard JJ, Longo FR (1972) Mechanistic study of the synthesis and spectral properties of mesotetraarylporphyrins. J Am Chem Soc 94, 3986-92.

23. Chen YH, Parr T, Holmes AE, Nakanishi K (2008) Porphyrinmaleimides: Towards thiol probes for cysteine residues in proteins. Bioconjugate Chem 19, 5-9.

24. Bettelheim A, White BA, Raybuck SA, Murray RW (1987) Electrochemical polymerization of amino-substituted, pyrrole-substituted and hydroxy-substituted tetraphenylporphyrins. Inorg Chem 26, 1009-17.

25. Long GL, Winefordner JD (1983) Limit of detection. A closer look at the IUPAC definition. Anal Chem 55, 712A-24A.

26. Miller JN, Miller JC (2000) Statistic and Chemometrics for Analytical Chemistry, Pearson Prentice Hall, Harlow.

27. Connors KA (1987) Binding Constants: The Measurement of Molecular Complex Stability, Wiley Interscience. New York.

28. Galardon E, Lukas M, Maux PL, Toupet L, Roisnel $\mathrm{T}$, Simonneaux T (2000) Bis $[(R)-1-$ phenylethyl isocyanido $](5,10,15,20$-tetrakis $\{2,6$-bis $[(S)$-2,2-dimethyl1,3-dioxolan-4-ylmethyloxy]phenyl $\}$ porphyrin)ruthenium(II) at $110 \mathrm{~K}$. Acta Crystallogr C56, 955-6.

29. Korotchenko VN, Severin K, Gagné MR (2008) The aerobic oxidation of alcohols with a ruthenium porphyrin catalyst in organic and fluorinated solvents. Org Biomol Chem 6, 1961-5.

30. Miessler GL, Tarr DA (2004) Inorganic Chemistry, Pearson Education International, New Jersy.

31. Principi P, Villa F, Bernasconi M, Zanardini E (2006) Metal toxicity in municipal wastewater activated sludge investigated by multivariate analysis and in situ hybridization. Water Res 40, 99-106.

32. Acheampong MA, Meulepas RJW, Lens PNL (2010) Removal of heavy metals and cyanide from gold mine wastewater. J Chem Tech Biotechnol 85, 590-613. 